\title{
DÜBLIN
}

Technological University Dublin ARROW@TU Dublin

2006-01-01

\section{Quarter-Wave Metal Plate Solar Antenna}

\author{
S. Shynu \\ Technological University Dublin \\ Max Ammann \\ Technological University Dublin, max.ammann@tudublin.ie \\ Brian Norton \\ Technological University Dublin
}

Follow this and additional works at: https://arrow.tudublin.ie/engscheceart

Part of the Electrical and Computer Engineering Commons

\section{Recommended Citation}

Shynu, S., Ammann, M. \& Norton, B. (2006) Quarter-Wave Metal Plate Solar Antenna. Electronics Letters, Vol.42, September, 2006, pp.1129-1130. doi:10.1049/el:20062015

This Article is brought to you for free and open access by the School of Electrical and Electronic Engineering at ARROW@TU Dublin. It has been accepted for inclusion in Articles by an authorized administrator of ARROW@TU

Dublin. For more information, please contact

arrow.admin@tudublin.ie, aisling.coyne@tudublin.ie, gerard.connolly@tudublin.ie. Funder: Science Foundation Ireland 


\section{Quarter-wave metal plate solar antenna}

\section{S.V. Shynu, M.J. Ammann and B. Norton}

A novel design of a quarter-wave shorted trapezoidal metal plate solar antenna using high efficiency polycrystalline silicon solar cells is presented. Using the DC conductive parts of the cell as RF antenna elements as well as choosing the radiating element to be a small base trapezoid, better coupling between the feed and shorting plates is ensured and $40.3 \%$ size reduction compared to a conventional shorted quarter-wave patch is obtained. The trapezoidal radiating element covers merely $2.7 \%$ of the total available illumination area of the solar cell, leaving its efficiency essentially unaffected. The proposed design strategy has been verified by an instantiation operating at $1.957 \mathrm{GHz}$ and has a wide impedance bandwidth of $15.2 \%$ with a gain of $4.5 \mathrm{dBi}$.

Introduction: The integration of photovoltaic (PV) solar cells and the antenna into a single unit can address the critical needs of reduced mass, physical size and cost of enabling technologies that will offer futuristic applications in autonomous wireless communication systems and deep space missions. Locating photovoltaic cells behind the microstrip reflect array antenna and integration of amorphous silicon solar cells with a slot antenna offers promising solutions $[1,2]$. But most of these solar antenna designs suffer from low solar cell efficiency owing to increased RF radiating surface area, which reduces the total available illumination area for the photovoltaic cell. Moreover, these designs undergo poor return loss, bandwidth and gain performance inherent with microstrip patch designs [3]. The key to providing a flexible solution is to have the RF radiating element small compared to the integrated solar cell and the simultaneous use of the DC conductive parts of the cell as RF antenna elements. In this Letter we propose the novel design of a solar antenna with high efficiency polycrystalline silicon solar cells where the RF radiating element size is greatly reduced using a trapezoidal shorted quarter-wave metal plate. The DC conductive silver bus bars of the PV cell form the RF reflecting ground plane in order to accomplish total integration of the two technologies.

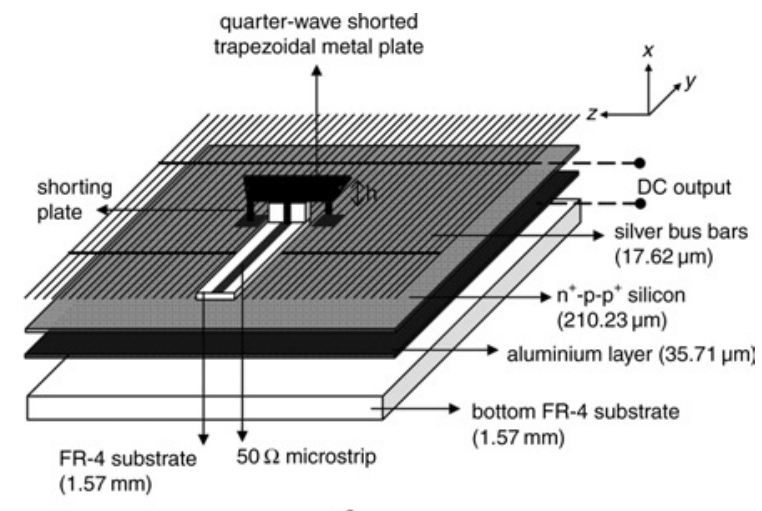

a

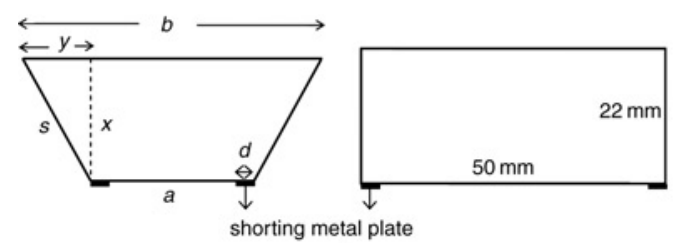

$b$

Fig. 1 Expanded layout of proposed quarter-wave trapezoidal metal plate solar antenna, and topology of quarter-wave trapezoidal $R F$ radiating element and its equivalent quarter-wave rectangular metal plate

$a$ Expanded layout of proposed quarter-wave trapezoidal metal plate solar antenna $b$ Topology of quarter-wave trapezoidal RF radiating element and its equivalent quarter-wave rectangular metal plate.

$a=25 \mathrm{~mm}, b=48 \mathrm{~mm}, s=21.4 \mathrm{~mm}, x=18 \mathrm{~mm}, y=11.5 \mathrm{~mm}$ and $d=2 \mathrm{~mm}$

Antenna design: The configuration of the proposed solar antenna with different constituting layers is shown in Fig. $1 a$. The polycrystalline-Si solar cell with dimensions of $15.6 \times 15.6 \times 0.026 \mathrm{~cm}$ comprises three layers with an aluminium back contact of thickness $35.71 \mu \mathrm{m}$ and a silicon $\mathrm{n}^{+}-\mathrm{p}-\mathrm{p}^{+}$layer with $210.23 \mu \mathrm{m}$ thickness. The $17.62 \mu \mathrm{m}$ thick silver DC bus bars form the third layer on top. A bottom FR-4 dielectric layer is used for mechanical support. The topology of the RF radiating element and its equivalent quarter-wave shorted rectangular metal plate is shown in Fig. 1b. A trapezoidal metal plate with a small base width is selected in an attempt to increase the strong capacitive coupling between the feed and shorting plates and thereby reduce the resonant frequency and physical size of the radiating element $[4,5]$. The radiating surface area of the $0.2 \mathrm{~mm}$-thick $\mathrm{Cu}$ trapezoidal metal plate is only $6.57 \mathrm{~cm}^{2}$, compared to $11 \mathrm{~cm}^{2}$ of the regular rectangular quarter-wave metal plate antenna, giving a $40.3 \%$ size reduction. The reduction in solar cell efficiency due to the shadowing of the trapezoidal metal plate radiating element and its feeding is marginal since it covers merely $2.7 \%$ of the total available illumination area of the solar cell. Two shorting metal plates of width $d=2 \mathrm{~mm}$ connect the trapezoidal metal plate with the solar cell silver DC bus bars (Fig. 1). The silver bus bar orientation is chosen along the $y$-axis, parallel to the resultant electric field in the shorted trapezoidal metal plate. The DC bus bars with $2.78 \mathrm{~mm}$ spacing form the RF ground for the $50 \Omega$ microstripline feeding mechanism. A finite integral equation based full-wave electromagnetic simulator (CST Microwave Studio) is used to optimise the solar antenna for better bandwidth and gain performance. The maximum initial electrical conductivity of the cell in the dark state is $380.8 \mathrm{Sm}^{-1}$, which will vary with incident photon flux density. Standard conductivity values are used for $\mathrm{Al}$ and $\mathrm{Ag}$ for simulation purpose.

The optimised quarter-wave trapezoidal metal plate radiating element has a width, $b=48 \mathrm{~mm}$, base width, $a=25 \mathrm{~mm}$ and a side length, $s=$ $21.4 \mathrm{~mm}$. The metal plate is placed $h=10 \mathrm{~mm}$ above the solar cell silver DC bus bars. Two small metal patches of dimensions $4 \times 4 \mathrm{~mm}$ are used to fix the shorting plates with the thin silver bars of the solar cell for better ground connection. The $3 \mathrm{~mm}$-wide $50 \Omega$ microstrip feed is fabricated on a substrate of dimensions $68 \times 10 \times 1.57 \mathrm{~mm}$ with a dielectric constant $\varepsilon_{r}=4.3$ and $\tan \delta=0.015$. Two RF blocking inductors are used at the DC load of the solar cell for good isolation between DC and RF functions. The performance of the proposed trapezoidal metal plate solar antenna (TMPSA) is then compared with a rectangular metal plate solar antenna (RMPSA) where the radiating element is replaced with a regular shorted quarter-wave metal plate.

Results: The measured and simulated $\mathrm{S}_{11}$ of the proposed solar antenna (TMPSA) and the rectangular metal plate solar antenna (RMPSA) are given in Fig. 2, showing good agreement. A wide $-10 \mathrm{~dB}$ impedance bandwidth of $15.2 \%$ is achieved for the proposed solar antenna design in the $1.957 \mathrm{GHz}$ band compared to $12.7 \%$ of the RMPSA operating at $2.073 \mathrm{GHz}$. The solar antenna gain in the entire operating frequency band is measured and plotted in Fig. 3. The trapezoidal metal plate solar antenna provides a higher gain of $4.5 \mathrm{dBi}$ compared to $3.7 \mathrm{dBi}$ of the RMPSA. Comparison of the normalised measured and simulated radiation patterns of the proposed solar antenna for the elevation and azimuth plane is shown in Fig. 4. Broad radiation patterns are achieved for the solar antenna with good agreement between the measured and simulated patterns. The H-plane radiation patterns show a higher level of cross polarisation as observed in other shorted patch antenna designs [6]. A slight improvement in cross-polarisation is also observed with TMPSA compared to RMPSA. The measured reduction in solar cell efficiency of the proposed TMPSA design is only $3.46 \%$ compared to $5.15 \%$ for the RMPSA.

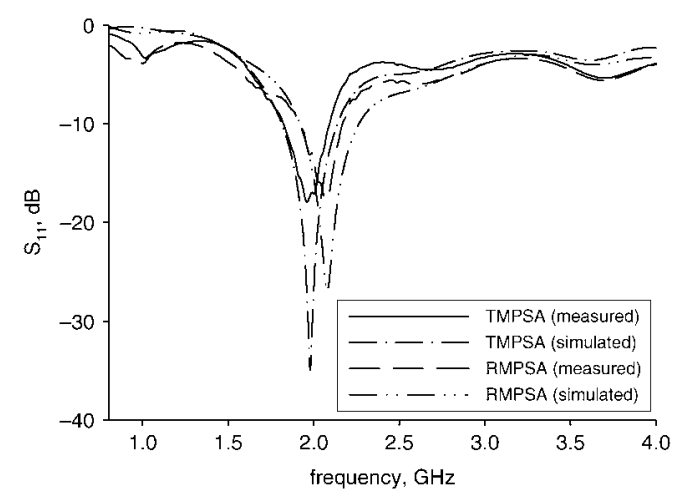

Fig. 2 Measured and simulated $S_{11}$ of solar antennas 


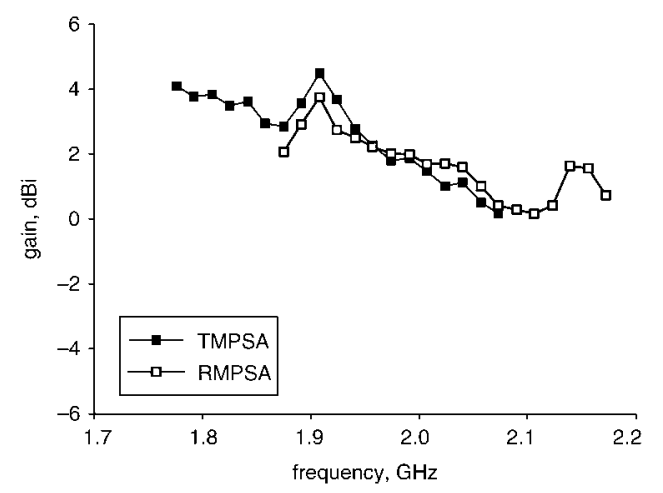

Fig. 3 Comparison of measured gain of proposed TMPSA with RMPSA
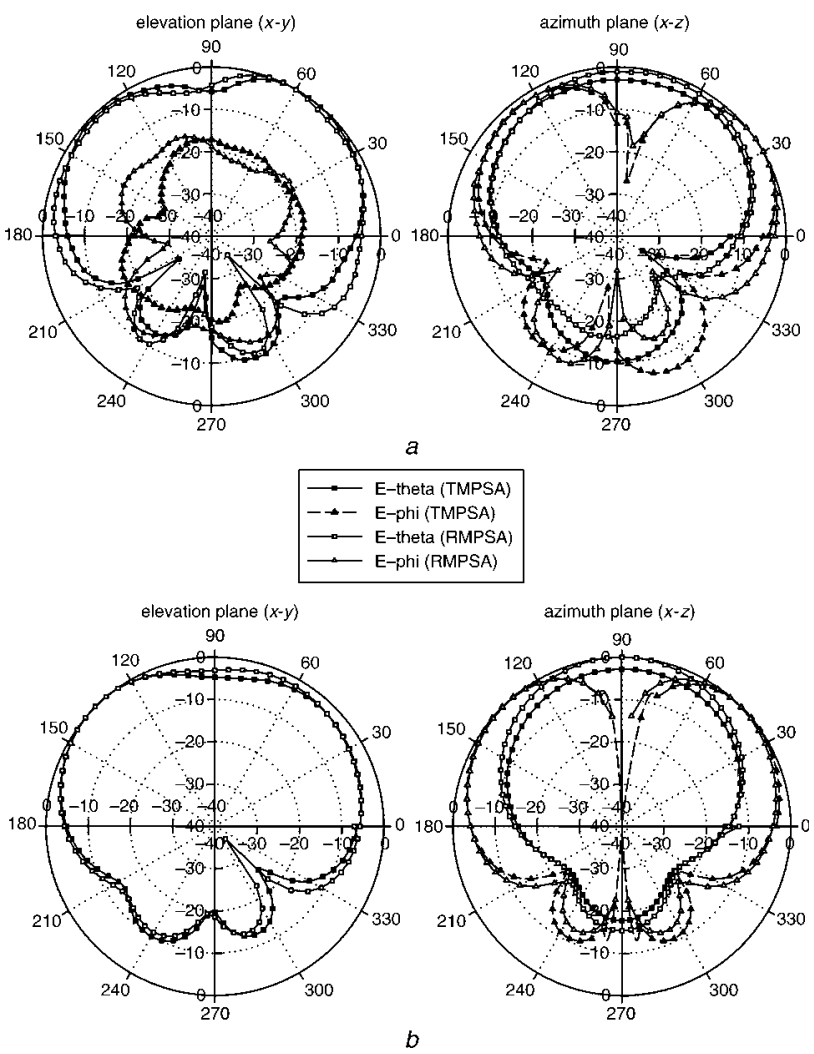

Fig. 4 Radiation patterns of solar antennas

$a$ Measured

$b$ Simulated (simulated cross-polarisation in elevation plane too small to be visible in above $\mathrm{dB}$ scale)
Conclusion: A novel design of a quarter-wave shorted trapezoidal metal plate solar antenna is proposed using high efficiency polycrystalline silicon solar cells. The design can achieve acceptable antenna performance without degrading the integrated solar cell efficiency.

Acknowledgement: This work was supported by Science Foundation Ireland.

(C) The Institution of Engineering and Technology 2008

6 March 2008

Electronics Letters online no: 20080645

doi: 10.1049/el:20080645

S.V. Shynu and M.J. Ammann (School of Electronic and Communications Engineering, Dublin Institute of Technology, Kevin Street, Dublin 8, Ireland)

E-mail: max.ammann@dit.ie

B. Norton (Dublin Energy Lab, Focas Institute, Dublin Institute of Technology, Dublin 8, Ireland)

\section{References}

1 Vaccaro, S., Mosig, J.R., and De Maagt, P.: 'Two advanced solar antenna SOLANT designs for satellite and terrestrial communications', IEEE Trans. Antennas Propag., 2000, 51, pp. 2028-2034

2 Zawadzki, M., and Huang, J.: 'Integrated RF antenna and solar array for spacecraft application'. IEEE Proc. Int. Conf. on Phased Array Systems and Technology, Danna Point, CA, USA, May 2000, Vol. 32 , pp. $239-242$

3 Henze, N., Weitz, M., Hofmann, P., Bendel, C., Kirchoff, J., and Fruchting, H.: 'Investigations on planar antennas with photovoltaic solar cells for mobile communications'. IEEE Int. Symp. on Personal Indoor and Mobile Radio Communications, Barcelona, Spain, April 2004, Vol. 1, pp. 622-626

4 Deshpande, M.D.: 'Analysis of quarter-wave shorted patch antenna'. IEEE Int. Symp. on Antennas and Propagation, Boston, MA, USA, July 2001, Vol. 2, pp. 704-707

5 Li, R.L., Dejean, G., Tentzeris, M.M., and Laskar, J.: 'Development and analysis of a folded shorted-patch antenna with reduced size', IEEE Trans. Antennas Propag., 2000, 52, pp. 555-562

6 Wong, K.L.: 'Planar antennas for wireless communications systems' (John Wiley \& Sons, New Jersey, 2003) 